Avoimesti luettavissa osoitteessa http://journal.fi/ainedidaktiikka

ainedidaktiikka

\title{
Ympäristö- ja kestävyyskasvatus osana ainedidaktiikkaa
}

Ympäristöön ja kestävään kehitykseen liittyvät teemat ovat opetuksen sisältöinä oppiainerajat ylittäviä ja niitä voidaan käsitellä opetuksessa kunkin tiedonalan omasta näkökulmasta. Moniin muihin oppiainerajat ylittäviin teemoihin verrattuna ympäristöteemojen erityispiirre kuitenkin on, että niiden sisällöt ulottuvat luonnontieteiden ja ihmistieteiden välisen rajan yli, mikä tuo lisähaastetta aihepiirin tiedonalalähtöiseen opetukseen. Samalla ympäristö- ja kestävyyskasvatukseen sisältyy muutoksen tekemisen haaste, kun vaatimukset transformaatiosta kohti kestävää elämäntapaa ja hiilineutraalia yhteiskuntaa lisääntyvät.

Kutsuimme tämän teemanumeron kirjoittajiksi ainedidaktiikan tutkijoita eri tiedonaloilta esittelemään tutkimustuloksiaan ja pohtimaan ympäristö- ja kestävyyskasvatusta ainedidaktiikan näkökulmasta. Miten ympäristö- ja kestävyyskasvatusta toteutetaan eri tiedonaloja tukien? Millaista monialaista ainedidaktiikkaa ympäristö- ja kestävyyskasvatuksen saralla on luonteva toteuttaa? Miten kasvatus voi toimia muutoksen tekijänä kestävään yhteiskuntaan siirryttäessä?

Teemanumeron artikkeleissa ympäristö- ja kestävyyskasvatusta käsitellään monien oppiaineiden ja tieteen- ja tiedonalojen näkökulmista: biologian, maantieteen ja luonnontieteiden lisäksi mukana on myös kirjallisuuden ja alakoulun opetuksen näkökulmat. Artikkelit tarkastelevat monipuolisesti ympäristö- ja kestävyyskasvatuksen eri teemoja, kuten ilmastokasvatusta, tulevaisuuskasvatusta, sosiaalisen ja taloudellisen kestävyyden näkökulmia sekä oppijan toimijuutta.

Ilmastokasvatuksen haasteena on paitsi opetettavan sisällön monimutkainen luonne, myös aihepiirin herättämä huoli ja muut tunteet. Ilkka Ratinen ja Reetta Pahtaja käsittelevät artikkelissaan alakoulussa toteutettavaa ilmastokasvatusta ratkaisukeskeisestä näkökulmasta. He korostavat tutkivan oppimisen tärkeyttä ja oppilaiden omien, arkisiin kokemuksiin perustuvien näkemysten huomioonottamista. Oppilaiden pohdinnat omien tekojensa merkityksellisyydestä ja heidän ilmastonmuutokseen liittyvien 
tunteidensa huomioinen voivat tukea opetuksen vuorovaikutuksellisuutta ja toivon ylläpitämistä.

Sari Vuorenpää, Lili-Ann Wolff ja Pia Sjöblom tarkastelevat artikkelissaan luonnontieteen opetusta yhdenvertaisuuden ja sosiaalisen kestävyyden edistämisen näkökulmista. Luokkahuonetutkimuksessaan kirjoittajat analysoivat opettajan tekemiä didaktisia valintoja ja luonnontieteellisen lukutaidon opetusta suomalaisen ja ruotsalaisen 5. luokan opetuksessa. Tutkijat korostavat vuorovaikutuksen merkitystä: sen avulla erilaisten oppijoiden osallisuuden kokemusta - ja samalla luonnontieteellisen sisällön oppimista - voidaan tukea.

Globaalien ympäristökriisien ymmärtäminen ja niihin reagoiminen edellyttävät luonnontieteellisen sisältötiedon ja sen arkipäivän sovellusten hallintaa, mutta ne eivät kuitenkaan yksin riitä. Antti Laherto korostaa artikkelissaan, kuinka luonnontieteiden opetuksessa tarvitaan myös vastuullisen toimijuuden esiin tuomista. Arvojen muutosta tarvitaan sekä yksilön että yhteiskunnan tasolla. Tulevaisuudentutkimus tarjoaa Laherton mukaan tärkeitä lähestymistapoja olemassa olevien vaihtoehtojen ja yksilön vaikutusmahdollisuuksien tunnistamiseen. Skenaarioajattelun avulla voidaan pyrkiä vahvistamaan opiskelijoiden toimijuuden kokemuksia.

Julia Leivo, Olli Ruth ja Petteri Muukkonen analysoivat artikkelissaan maantieteen ylioppilaskokeiden taloudellista kestävyyttä käsitteleviä kysymyksissä ja kokelaiden esseevastauksia. Tutkijoiden kiinnostuksen kohteena on se, millaista ajattelun tasoa tehtävät edellyttävät ja millaista ajattelun taitoa aineistoon valikoituneiden vastaajien esseissä esiintyy. Kirjoittajat tarkastelevat myös sitä, millaista tietoa kokelailla on taloudellisen kestävyyden teemoista. Esitellessään seikkaperäisen analyysinsa tuloksia Leivo ja kumppanit toteavat, että huolimatta siitä, että opiskelijat osasivat pohtia kestävään kehitykseen liittyviä sisältöjä, he eivät kuitenkaan juuri tuoneet esille kestävän kehityksen perusajatusta siitä, kuinka taloudellinen kehitys ei saisi tapahtua ympäristön tai tulevien sukupolvien kustannuksella.

Eija Yli-Panula, Eila Jeronen, Salla Koskinen ja Sofia Vesterkvist tarkastelevat tutkimuksessaan ilmastonmuutoksen opetuksessa käytettyjä opetusmenetelmiä biologian ja maantieteen opetuksen kontekstissa. Artikkelin aineistona ovat tieteelliset artikkelit, joiden sisältämiä opetusmenetelmiä kirjoittajat erittelevät. He analysoivat myös sitä, millaista oppilaiden tiedon ja ajattelun tasoa artikkeleissa esitellyt menetelmät tukevat. Yleisemmin käytettyjä opetusmenetelmiä olivat tutkiva oppiminen, ongelmanratkaisutehtävät, ryhmätyöt sekä erilaiset opettajakeskeiset menetelmät. Usein ilmastonmuutoksen opetuksessa käytettiin monia menetelmiä yhdessä. Niiden avulla pyrittiin tukemaan monimutkaisten asioiden oppimista.

Kuten edellä esitellyt artikkelit tuovat ilmi, teemanumeromme houkutteli monia luonnontieteen didaktiikan tutkijoita. Tämä ei ollut meille yllätys, sillä ympäristö- ja kestävyyskysymykset mielletään yhä edelleen usein erityisesti luonnontieteiden alaan kuuluviksi. On kuitenkin hyvä huomata, kuinka monissa artikkeleissa luonnontieteiden rinnalle on tuotu tarve ihmistieteellisten näkökulmien aiempaa vahvemmasta huomioon 
Ainedidaktiikka 4(3) (2020)

ottamisesta. Ympäristö- ja kestävyyskysymykset kaikessa monimutkaisuudessaan vaativat laaja-alaista ymmärrystä ja tieteenalojen välistä yhteistyötä.

Virkistävän poikkeuksen teemanumeromme artikkeleiden joukossa tarjoaa Päivi Koponen, joka tarkastelee peruskoulun ja lukion äidinkielen ja kirjallisuuden oppiaineen sisällä tapahtuvan kirjallisuuden opetuksen ympäristöpedagogisia mahdollisuuksia. Koponen soveltaa sarjakuvaromaanin analyysissaan filosofisessa ja ihmistieteellisessä tutkimuksessa 2000-luvun aikana tapahtunutta materiaalista käännettä tuoden vuoropuheluun monilukutaidon pedagogiikan kanssa. Toivomme, että Koposen artikkeli voisi toimia innostavana esimerkkinä muille tutkijoille siitä, kuinka ympäristö- ja kestävyyskasvatuksen aihepiiri ei ole vain luonnontieteiden "omaisuutta", vaan tarvitsemme tulevaisuudessa kipeästi tutkimusta mahdollisimman laajalta ainedidaktiikan kentältä.

\author{
Sirpa Tani ${ }^{1}$ ja Essi Aarnio-Linnanvuori ${ }^{2}$ \\ ${ }^{1}$ Helsingin yliopisto, Kasvatustieteellinen tiedekunta \\ ${ }^{2}$ Tampereen yliopisto, Kasvatustieteiden ja kulttuurin tiedekunta
}

